\title{
MECHANICAL BEHAVIOR OF COLD BITUMINOUS MIXTURE UNDER EFFECTS OF STATIC AND REPEATED LOADS ${ }^{1}$
}

Tamyres Karla da Silva ${ }^{2}$, Carlos Alexandre Braz de Carvalho ${ }^{3}$, Geraldo Luciano de Oliveira Marques ${ }^{4}$, Dario Cardoso de Lima $^{3}$, Taciano Oliveira da Silva ${ }^{3 *}$ and Carlos Cardoso Machado ${ }^{5}$

\footnotetext{
${ }^{1}$ Received on 11.04.2014 accepted for publication on 28.11.2016.

${ }^{2}$ Universidade de Brasilia, Programa de Pós-Graduação em Geotecnia, Distrito Federal - Brasil. E-mail:<tamyreskarla@gmail.com>.

${ }^{3}$ Universidade Federal de Viçosa, Departamento de Engenharia Civil, Viçosa Minas Gerais, Brasil. E-mail: <cabraz@ufv.br>, <declima@ufv.br>and<taciano.silva@ufv.br>.

${ }^{4}$ Universidade Federal de Juiz de Fora, Departamento de Transporte e Geotecnia, Juiz de Fora, Brasil. E-mail: <geraldo.marques@ufjf.edu.br>.

${ }^{5}$ Universidade Federal de Viçosa, Departamento de Engenharia Florestal, Viçosa, Minas Gerais, Brasil. E-mail:<machado@ufv.br>.

*Corresponding author.
}

\begin{abstract}
This paper presents the results of an experimental research aimed at analyzing the mechanical behavior of a cold bituminous mixture under effects of static and repeated loads. Initially, a Marshall mixture design was performed to determine the mixture design contents according to standard DNER (1994a). After obtaining the mixture design contents, nine bituminous specimens were molded and subjected to the following tests: resilient modulus, tensile strength by diametral compression, and fatigue. The Marshall stability, independent from the mixture content used, surpassed the minimum limit recommended by the service specification DNIT (2010a). Regarding the Marshall flow, the values found exceeded the required by the referred specification. The results obtained for the average tensile strength by diametral compression, resilient modulus and fatigue life of the bituminous mixture were, respectively, $0.47 \mathrm{MPa}$, in the range of 1530-1837 MPa, and lower than 1000 cycles (for most stress differences applied), which were lower than those commonly reported for hot mixtures.
\end{abstract}

Keywords: Marshall mixture design; Resilient modulus and tensile strength by diametral compression

\section{COMPORTAMENTO MECÂNICO DE UMA MISTURA BETUMINOSA A FRIO SOB EFEITOS DE CARGAS ESTÁTICAS E REPETIDAS}

\begin{abstract}
RESUMO - Este trabalho apresenta resultados oriundos de uma pesquisa experimental cujo o objetivo foi analisar o comportamento mecânico de uma mistura betuminosa a frio sob efeitos de cargas estáticas e repetidas. Inicialmente, fez-se uma dosagem Marshall para definição do teor de projeto da mistura, de acordo com a norma DNER (1994a). Após obtenção do teor de projeto, foram moldadas nove amostras para serem submetidas aos seguintes ensaios: módulo de resiliência, resistência à tração por compressão diametral e fadiga. Verificou-se que a estabilidade Marshall, independente do traço utilizado, superou o limite mínimo recomendado na especificação de serviço DNIT (2010a). Quanto à fluência, os valores encontrados superaram os exigidos na referida especificação. Os resultados obtidos para a resistência à tração por compressão diametral média, módulo de resiliência e vida de fadiga da mistura betuminosa foram, respectivamente, de 0,47 MPa, na faixa de 1.530 a 1.837 MPa e menores que 1.000 ciclos (para a maioria das diferenças de tensão aplicadas), os quais foram inferiores àqueles comumente relatados para misturas a quente.
\end{abstract}

Palavras - Chave: Dosagem Marshall; Módulo de resiliência e resistência à tração por compressão diametral. 


\section{INTRODUCTION}

According to the statistical bulletin of the National Confederation of Transport - CNT (CNT, 2016), the Brazilian road network is of the order of $211,378 \mathrm{~km}$ of paved roads and 1,352,017 km of unpaved roads. Bernucci et al. (2008) comment that about $95 \%$ of the paved roads in Brazil have asphalt pavements, which are still very much used in urban roads.

Asphaltic coatings are bituminous mixtures made up of aggregates and asphaltic materials, asphalt binders, which can be obtained by penetration or by mixing. When obtained by mixing, they are made in the plant or on the track, where the aggregate is pre-enveloped with the hot or cold asphalt material before compression (Bernucci et al., 2008).

The presence of the aggregates is of the order of $95 \%$ by weight in dry asphalt mixture. The remainder is due to the presence of the binder. In this way, it is fundamental to know the technological properties of the aggregate to obtain a good design of an asphalt mixture.

Particle size is one of the most important physical properties of aggregates. After mixing with the binder, aggregate particle size will influence stiffness, stability, fatigue strength, workability, durability, permeability and permanent deformation of the mixture. Through the sieving, it is possible to obtain the different fractions of the grains that make up an aggregate.

Asphaltic binders are thermo-sensitive materials which, when used in a mixture with aggregates, affect the mechanical response of the mixture by varying not only the amplitude, frequency and duration of the load, but above all by the temperature variation.

According to Santos (2002), the cold pre-mixed asphalt mixture can be used as a rolling layer of new or recapped pavements and in maintenance services of roads and urban roads. When the mixture is properly protected, it has the advantage of being able to be stored for a few days, which facilitates the production and application of the same.

In the evaluation of the mechanical behavior of the bituminous mixture studied, we used: (i) Marshall test, which contains the procedures and parameters for cold bituminous mixtures; (ii) tensile strength by diametral compression, which is based on the application of a bursting load vertically on two metal strips disposed in the longitudinal direction of the specimen; (iii) resilient modulus test, which deals with the relationship between the tensile stress $\mathrm{s}_{\mathrm{t}}$, applied repeatedly in the vertical diametral plane of a cylindrical specimen of a bituminous mixture and the specific recoverable deformation $\left(\mathrm{e}_{\mathrm{t}}\right)$ corresponding to the applied stress, at a given temperature e; (iv) fatigue test, which refers to the phenomenon of cracking induced by repeated loads, where the stress or deformation levels resulting therefrom are below the strength of the material.

This study aimed to analyze the physical-mechanical properties of a cold asphalt mixture, in accordance with the technical recommendations contained in technical standards of the former National Department of Roadways (DNER) and the National Department of Transport Infrastructure (DNIT), as well as to provide information on the behavior of cold asphalt mixtures under the effect of repeated loads, through determination of the resilient modulus and fatigue life.

\section{MATERIALAND METHODS}

The materials used in this research were aggregates (gravel 0, gravel 1 and gravel powder), gneiss formation, from the Ervália quarry, located in the city of Ervália, State of Minas Gerais, and the slow-setting cationic asphalt emulsifier RL-1C from Ipiranga Asfalto S.A., located in the city of Betim, State of Minas Gerais.

The method employed comprises several steps, each of which contains its peculiarities as follows.

Step 1: consisted of identifying the physical properties of the aggregates and the emulsion through the following tests: Los Angeles abrasion (DNER, 1998a); particle size analysis (ABNT, 2003a); large aggregate: specific gravity, apparent specific gravity and water absorption (ABNT, 2003b); fine aggregate: Chapman specific gravity (DNER, 1998b); large aggregate: adhesiveness to the bitumen binder (DNER, 1994b); Saybolt Furol viscosity (ABNT, 2007a); evaporation residue, \% in weight (ABNT, 2007b); sieving (ABNT, 1999); and particle charge (DNIT, 2011).

Step 2: choice of working range (DNIT, 2010a). We chose the range $\mathrm{C}$ (between open and dense mixtures). Due to the particle size of the aggregates, it was possible to obtain the percentage in weight of each of them in the mixture to meet the selected working range. 
Step 3: identification of the physical-mechanical properties of asphalt mixtures by means of the Marshall design (DNER, 1994a) using Equations 1-5 presented in Table 1 and the specific gravity and apparent density test of compacted bituminous mixtures referred to in American Society for Testing and Materials (ASTM, 2005). In the Marshall mixture design, it was studied four mixture contents of asphalt emulsion in weight $(6.5 \%$, $7.5 \%, 8.5 \%$ and $9.5 \%$ emulsion), expecting that by testing these contents we achieve the design content for the mixture. For each content, three specimens weighing about 1,200 $\mathrm{g}$ each were used. The specimens were compacted with 75 blows (Marshall hammer) on each side. It was also determined the Marshall flow using an attached dial gauge that measured the specimen's plastic flow as a result of the loading at the moment of specimen failure.

Step 4: definition of the design emulsion content $\left(\mathrm{T}_{\text {emulsion project }}\right)$ for the mixture, together with the proportion of the aggregates in weight (DNIT, 2010a). In this design content, nine specimens were molded for the resilient modulus test (DNIT, 2010b). In this test, the stress levels applied were considerably low. Thus, it was considered non-destructive. From the above sampling, three specimens were subjected to the tensile strength test by diametral compression (DNIT, 2010c); the remainder (six samples) was assigned to the fatigue test following the instructions of Mendes (2011), with a test temperature of $25^{\circ} \mathrm{C}$, applied stresses of $40 \%$, $35 \%, 30 \%, 25 \%, 20 \%$ and $15 \%$ of tensile strength by diametral compression. In this test, the statistical analysis was performed by linear regression, with determination of the coefficient of determination $\mathrm{R}^{2}$. Dynamic tests (resilient modulus and fatigue) and tensile strength by diametral compression tests were performed at the Pavement Laboratory, Faculty of Engineering of UFJF, Juiz de For a, State of Minas Gerais. Table 1 contains the equations used in the tests tensile strength by diametral compression, resilient modulus and fatigue.

\section{RESULTS}

Next, the results of the laboratory tests obtained in this research will be presented.

\subsection{Material characterization tests}

The Los Angeles abrasion found was $27 \%$ for gravel 0 and $22 \%$ for gravel 1 . The specific gravity found for gravel 0 was $29.1 \mathrm{kN} / \mathrm{m}^{3}$; for gravel 1 was $28.5 \mathrm{kN} /$ $\mathrm{m}^{3}$ and for the gravel powder was $28.0 \mathrm{kN} / \mathrm{m}^{3}$.
The distributions of aggregate size of the materials are shown in Figure 1. The percentages of the aggregates obtained to meet the range $\mathrm{C}$ of the specification (DNIT, 2010a), using the Rothfucks method, were $36 \%$ gravel $1,39 \%$ gravel 0 and $25 \%$ gravel powder (Figure 1 ). The adhesiveness to the asphalt binder was satisfactory.

When working with the asphalt emulsion RL-1C, we obtained the following results: a Saybolt Furol viscosity at $25^{\circ} \mathrm{C}$ of 25 ; evaporation residue, $\%$ in weight, of 61.02; the value of 0.34 for the sieve test (residue on the $0.84 \mathrm{~mm}$ sieve), $\%$ in weight of CAP and positive particle charge.

\subsection{Mechanical tests of bituminous mixtures}

\subsubsection{Marshall test}

The results of the Marshall mixture design indicators for the four contents in weight $(6.5 \%, 7.5 \%, 8.5 \%$ and 9.5\% emulsion) are shown in Figure 2. The Marshall flow presented values of the order of $6.25 \mathrm{~mm} ; 6.30$ $\mathrm{mm}, 6.90 \mathrm{~mm}$ and $7.98 \mathrm{~mm}$. According to Bernucci et al. (2008), the design content can be obtained by the mean value of the three contents corresponding to the maximum stability, maximum apparent specific gravity and mean void volume of specifications. In agreement with Santana (1993), for cold dense pre-mix, it is required a percentage of voids between 9 and $15 \%$, adopting $11 \%$ in this research. Thus, based on these considerations, the design emulsion content for the mixture $\left(\mathrm{T}_{\text {emulsionproject }}\right)$ was found to be $8.0 \%$.

\subsubsection{Tests of tensile strength by diametral compression}

As a result of the test of tensile strength by diametral compression (RT), for the $8.0 \%$ content, for the specimen 1 , which presented a mean height of $6.69 \mathrm{~cm}$, it was obtained a mean diameter of $10.08 \mathrm{~cm}$, a RT of 0.46 MPA. For test specimen 2, which had a mean height of $6.65 \mathrm{~cm}$, a mean diameter of $10.13 \mathrm{~cm}$, a RT of 0.52 MPA and, for test specimen 3, which had a mean height of $6.67 \mathrm{~cm}$, a mean diameter of $10.13 \mathrm{~cm}$, a RT of 0.44 MPA.

\subsubsection{Resilient modulus tests and fatigue tests}

Table 2 contains the results of the resilient modulus (MR) test of a cold bituminous mixture with $8.0 \%$ asphalt emulsion RL-1C; besides the results of the controlled stress fatigue test, under the temperature conditions

Revista Árvore. 2017;41(2):e410220 
Tabela 1 - Equações empregadas na dosagem Marshall e nos ensaios de resistência à tração por compressão diametral, módulo de resiliência e fadiga.

Table 1 - Equations used in the Marshall mixture design and testing tensile strength by diametral compression, resilient modulus and fatigue.

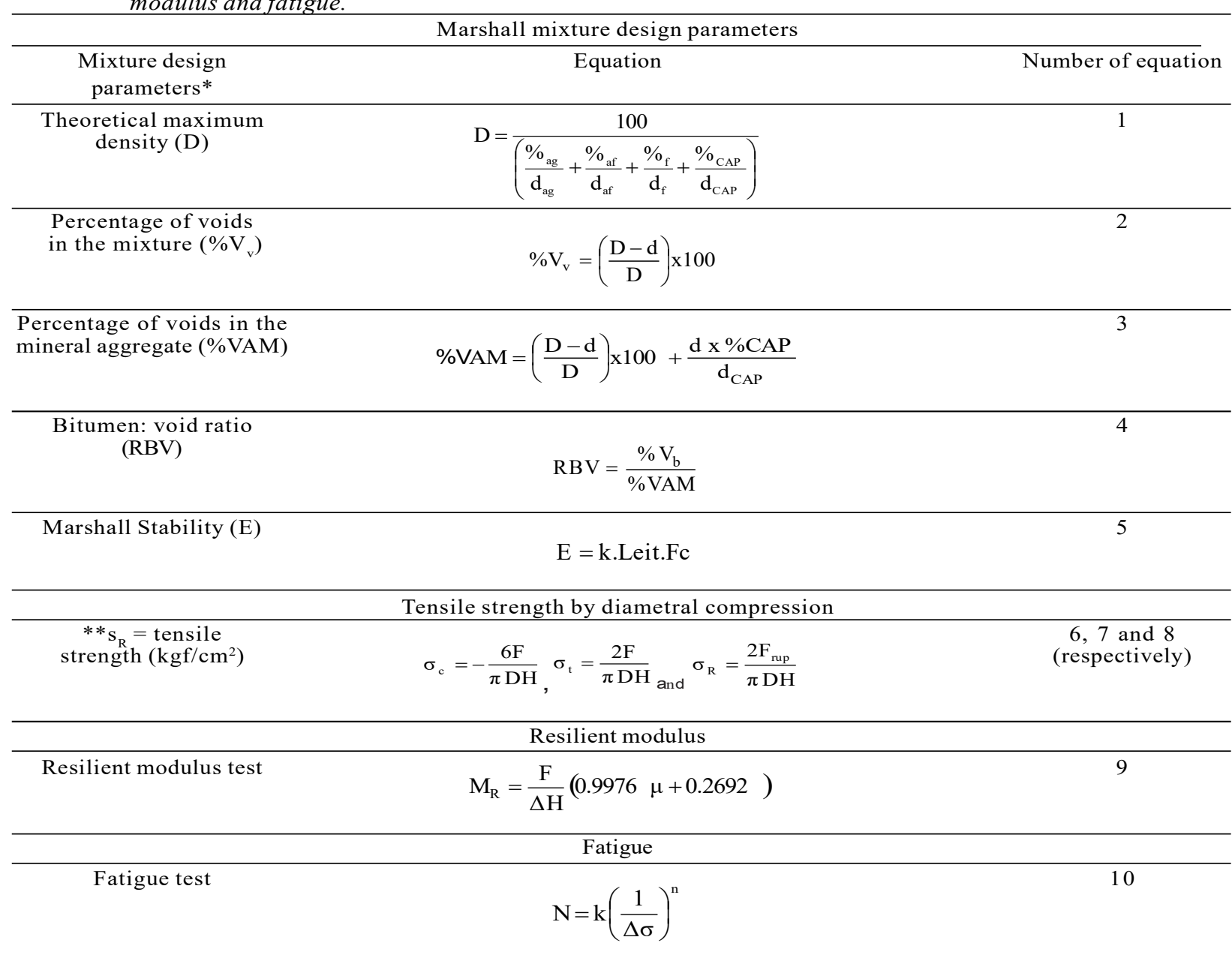

*d: apparent specific gravity of the mixture; $\%_{\mathbf{a g}}, \%_{\mathbf{a f}}, \%_{\mathrm{f}}$ and $\%_{\mathrm{CAP}}$ : percentages of large and fine aggregates, filler and petroleum asphalt cement, respectively; $\mathbf{d}_{\mathrm{ag}}, \mathbf{d}_{\mathrm{af}}, \mathbf{d}_{\mathbf{f}}$ and $\mathbf{d}_{\mathrm{CAP}}$ : real specific mass of large and fine aggregate grains, filler and petroleum asphalt cement, respectively; $\mathbf{V}_{\mathrm{b}}$ : volume of bitumen in the mixture; k: dynamometer ring constant; Leit: reading in the extensometer; Fc: correction factor as a function of the mean height of the specimen; R: tensile strength $\left(\mathrm{kgf} / \mathrm{cm}^{2}\right)$; Frup: bursting load (kgf); D: specimen diameter ( $\left.\mathrm{cm}\right)$; H: specimen height $(\mathrm{cm}) ; \mathrm{MR}$ : resilient modulus $\left(\mathrm{kgf} / \mathrm{cm}^{2}\right) ; \mathrm{F}$ : repeated vertical load applied diametrically on the specimen (kgf); $\Delta$ : elastic or resilient deformation recorded on the oscillograph, for 300, 400 and 500 load applications (F); $\mu$ : Poisson coefficient; N: fatigue life (number of repetitions of stress leading to sample failure; $\Delta \sigma$ : difference between compression and tensile stress: $($ Equation $8-$ Equation 7$)=4 \sigma_{t}$.

**when the applied load $(\mathrm{F})$ is not the bursting load, the maximum tensile stress $\left(\sigma_{t}\right)$ is given by Equation $(7)$ and the maximum compression stress $\left(\sigma_{c}\right)$ is given by Equation (8).

of $25^{\circ} \mathrm{C}$; mean resilient modulus of $1,673 \mathrm{MPa}$ and tensile strength by mean diametral compression of $0.47 \mathrm{MPa}$.

Table 2 and Figure 3 illustrate the behavior of the samples subjected to the fatigue test, and show the relationship between the difference of stresses applied with the fatigue life, and the relationship between specific resilient deformations.

\section{DISCUSSION}

The values of the specific gravity found for the aggregates are in accordance with the values found in other studies developed from the use of these materials from the same quarry, such as Montanari (2007).

The adhesiveness to the binder was satisfactory indicating that a good relationship between aggregate 

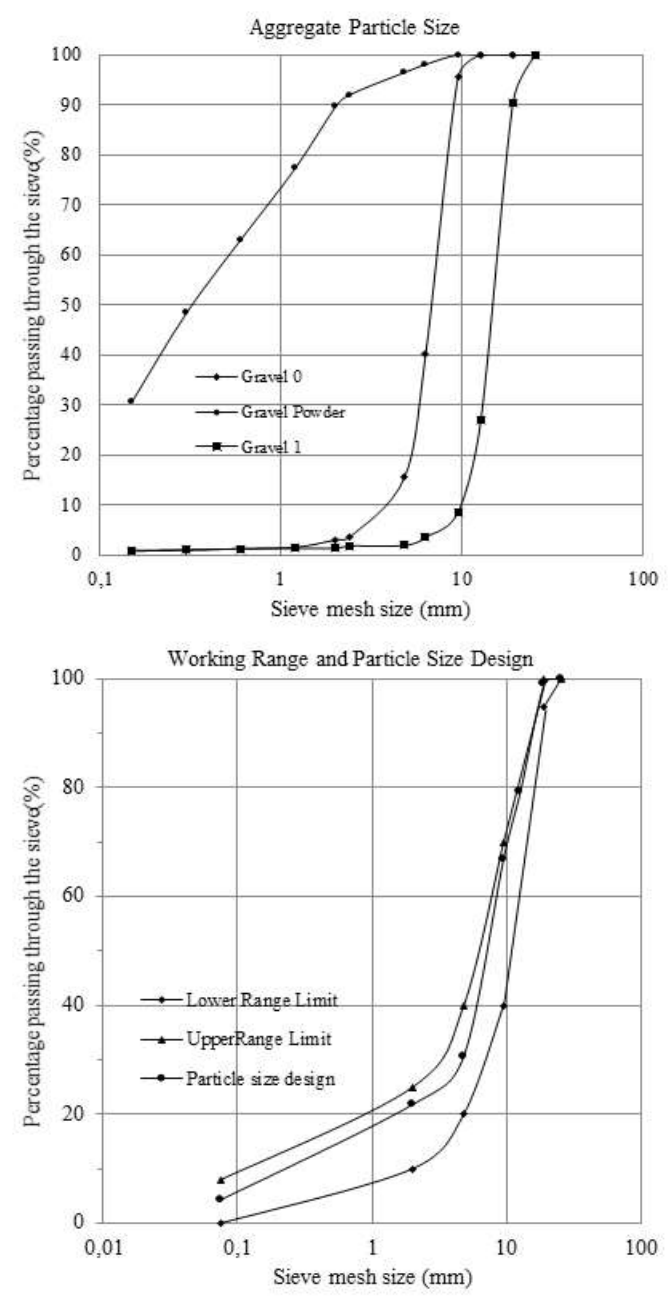

Figura 1 - Granulometria dos agregados e faixa de trabalho com granulometria do projeto.

Figure 1-Particle size of the aggregates and working range with a particle size of the project.

and binder will occur, with no need for the use of bitumen adhesion improvers or the exchange of materials used in this study.

The Los Angeles abrasion found for the materials under study met the service specification DNER (1998) for cold premix, since it was less than $40 \%$, indicating that the quality of the stony materials used was adequate.

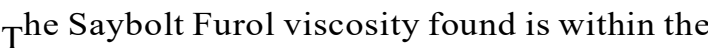
specification of the Brazilian Petroleum Institute (IBP, 1999), which is 20-100; the evaporation residue, \% in weight, found is slightly above the value recommended

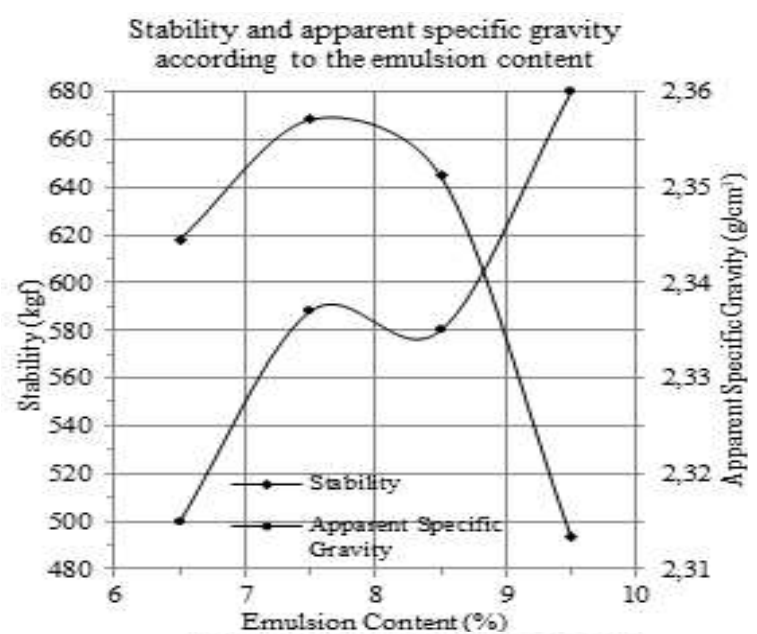

Fluency and percentage of voids according to the emulsion content
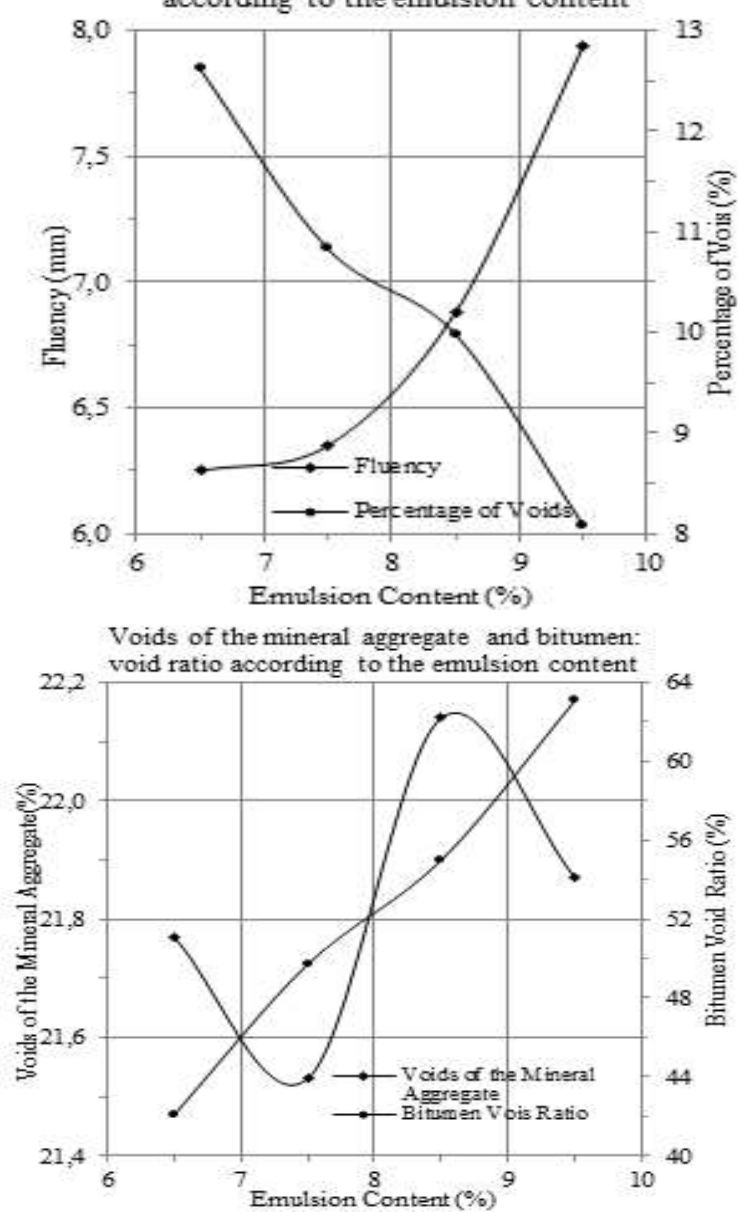

Figura 2 - Resultados dos indicadores de dosagem - ensaio Marshall.

Figure 2-Results of the indicators dosage - Marshall Test. 
Tabela 2 - Módulo de resiliência (MR) de uma mistura betuminosa a frio com 8,0\% de emulsão asfáltica do tipo RL - $1 \mathrm{C}$ e resultados obtidos no ensaio de fadiga à tensão controlada

Table 2 - Resilient modulus (MR) of a cold bituminous mixture with $8.0 \%$ asphalt emulsion type RL - $1 C$ and results obtained in the controlled stress fatigue test.

\begin{tabular}{|c|c|c|c|c|c|c|c|}
\hline \multicolumn{8}{|c|}{ Resilient modulus (MR) } \\
\hline $\begin{array}{l}\text { Sample } \\
\text { Number }\end{array}$ & $\begin{array}{l}\text { Height } \\
(\mathrm{cm})\end{array}$ & $\begin{array}{l}\text { Diameter } \\
(\mathrm{cm})\end{array}$ & $\begin{array}{c}\text { Emulsion } \\
\text { Content } \\
(\%)\end{array}$ & \multicolumn{2}{|c|}{$\begin{array}{c}\mathrm{M}_{\mathrm{R}} \\
(\mathrm{MPa})\end{array}$} & \multicolumn{2}{|c|}{$\begin{array}{c}\mathrm{M}_{\mathrm{R}} \\
(\mathrm{Mean}) \\
(\mathrm{MPa})\end{array}$} \\
\hline 1 & 6.69 & 10.08 & \multirow{9}{*}{8,0} & \multicolumn{2}{|c|}{1,821} & \\
\hline 2 & 6.65 & 10.13 & & \multicolumn{2}{|c|}{1,837} & & \\
\hline 3 & 6.67 & 10.13 & & \multicolumn{2}{|c|}{1,616} & & \\
\hline 4 & 6.72 & 10.07 & & \multicolumn{2}{|c|}{1,530} & & \\
\hline 5 & 6.72 & 10.16 & & \multicolumn{2}{|c|}{1,750} & \multicolumn{2}{|c|}{1,673} \\
\hline 6 & 6.63 & 10.12 & & \multicolumn{2}{|c|}{1,668} & & \\
\hline 7 & 6.62 & 10.20 & & \multicolumn{2}{|c|}{1,687} & & \\
\hline 8 & 6.68 & 10.17 & & \multicolumn{2}{|c|}{1,584} & & \\
\hline 9 & 6.66 & 10.12 & & \multicolumn{2}{|c|}{1,566} & & \\
\hline \multicolumn{8}{|c|}{ Controlled fatigue stress } \\
\hline $\begin{array}{l}\text { Sample } \\
\text { Number }\end{array}$ & $\begin{array}{c}\text { Thickness } \\
(\mathrm{cm})\end{array}$ & $\begin{array}{c}\text { Diameter } \\
(\mathrm{cm})\end{array}$ & $\begin{array}{c}\% \text { mean } \\
\mathrm{R}_{\mathrm{T}}\end{array}$ & $\begin{array}{l}\text { Strength* } \\
\text { (kgf) }\end{array}$ & $\begin{array}{c}\text { Specific } \\
\text { Resiliente } \\
\text { Deformation }\left(\mathrm{e}_{\mathrm{r}}\right)\end{array}$ & $\begin{array}{c}\text { Stress } \\
\text { Differences** } \\
(\mathrm{MPa})\end{array}$ & $\begin{array}{c}\text { Number of } \\
\text { Applications } \\
\text { of Stress }\end{array}$ \\
\hline 4 & 6.72 & 10.07 & 40 & 203.77 & 0.0001124 & 0.750 & 317 \\
\hline 5 & 6.72 & 10.16 & 35 & 179.90 & 0.0000983 & 0.660 & 448 \\
\hline 6 & 6.63 & 10.12 & 30 & 151.53 & 0.0000843 & 0.560 & 633 \\
\hline 7 & 6.62 & 10.20 & 25 & 127.08 & 0.0000702 & 0.470 & 720 \\
\hline 8 & 6.68 & 10.17 & 20 & 102.29 & 0.0000562 & 0.380 & 935 \\
\hline 9 & 6.66 & 10.12 & 15 & 76.11 & 0.0000421 & 0.280 & 1627 \\
\hline
\end{tabular}

* value obtained by applying Eq. 6 .

$* * 4\left(\mathrm{RT}_{\text {mean }}\right)\left(\% \mathrm{RT}_{\text {mean }}\right)$.

by the specification which is 60 ; the particle charge was in agreement with the IBP (1999) and the value found for the sieve test (residue on the $0.84 \mathrm{~mm}$ sieve), $\%$ in weight of CAP, is above the maximum value recommended by the corresponding specification, which is 0.1 .

The values found for the Marshall flow test did not meet the requirements of the specification (2.0$4.5 \mathrm{~mm}$ ); a probable reason may be related to the Marshall press used in the test, which is not automated, which made it difficult to register the flow at the time of sample rupture.

Regarding Marshall stability, regardless of the content used, all the specimens met the minimum requirement of $250 \mathrm{kgf}$ for 75 blows.

For the determination of the design content of the mixture, we considered: the maximum stability, the maximum apparent specific gravity and the void index of the mixture of $11 \%$, resulting in a design emulsion content for the mixture $\left(\mathrm{T}_{\text {emulsionproject }}\right)$ of $8.0 \%$.

Revista Árvore. 2017;41(2):e410220
The average tensile strength of $0.47 \mathrm{MPa}$, when compared to the values of strength cited by Medina and Motta (2005) for hot mixtures, fell short of the expected values for the PMF surfacing or asphalt layer; in turn, for the binder function, the values were more adequate.

Observing the values in Table 2 , it is verified that the resilient modules varied in the range from 1,530 to $1,837 \mathrm{MPa}$, values well below those presented by Medina and Motta (2005), page 305, using two types of CAP in layers of binder and surfacing layer for hot mixtures.

Regarding the fatigue life, this was also low. For most differences of stress applied, it was less than 1,000 applications. Specific resilient deformations ranged from $10^{-4}$ a $10^{-5} \mathrm{~mm} / \mathrm{mm}$. Statistically, it is worth mentioning that the linear regression models used to fit these equations were adequate since they presented coefficients of determination $\left(\mathrm{R}^{2}\right)$ higher than $97 \%$, both for the relationship between the difference of stresses applied with fatigue life as well as the relationship between specific deformations resilient with fatigue life. That 

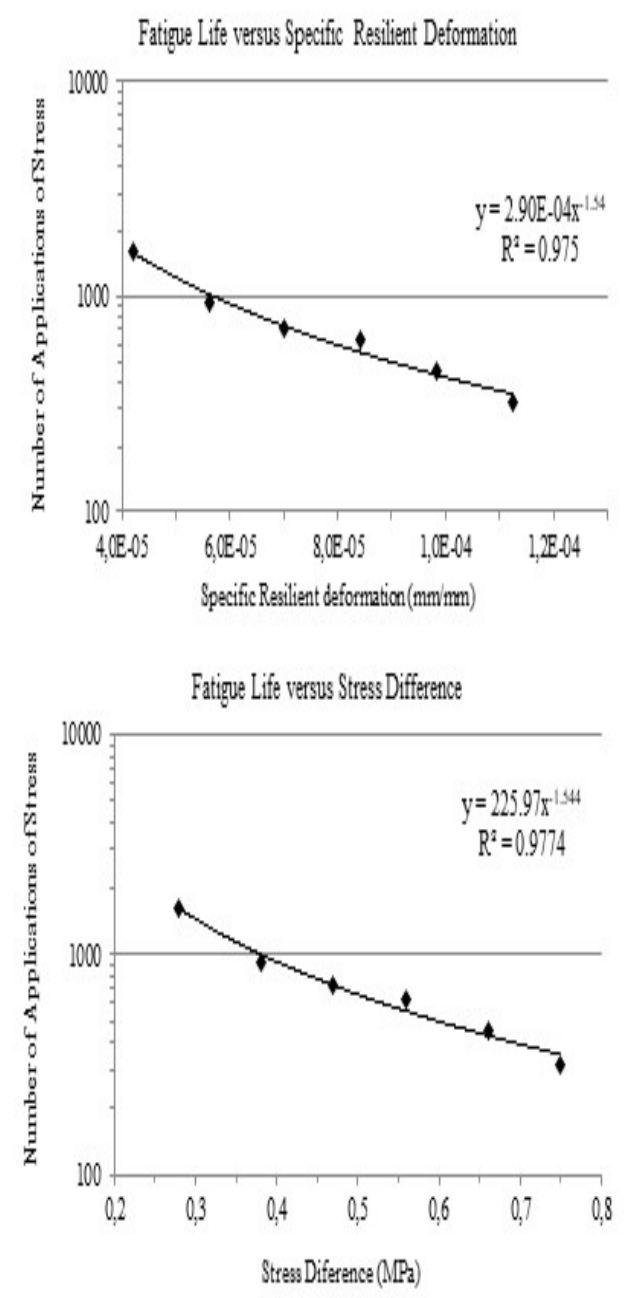

Figura 3 - Vida de fadiga em função da deformação específica resiliente e da diferença entre tensões.

is, approximately $97 \%$ of the dependent variable can be explained by the regression analysis present in the model; showing the magnitude of its fit to the sample.

\section{CONCLUSIONS}

The results of the Los Angeles abrasion and aggregate binder adhesiveness tests were satisfactory indicating the possibility of using these stony materials and the binder respectively in this research.

When working with the asphalt emulsion RL-1C, a value higher than that mentioned in the corresponding specification was found for the sieve test (residue on the

$0.84 \mathrm{~mm}$ sieve), although it is believed that a more accurate accomplishment of that test could solve this problem.

With respect to the minimum stability, via the Marshall test, all the specimens met the requirements of the service specification (DNIT, 2010a), differently from the Marshall flow test where it was observed that none of the values met the service specification.

Regarding the height of the samples, Marshall test, they exceeded the limit of $63.5 \mathrm{~mm} \pm 1.3 \mathrm{~mm}$, even when subjected to the compaction energy with 75 blows. Thus, it is recommended to review the particle size range in the $19.0 \mathrm{~mm}$ and $12.7 \mathrm{~mm}$ sieves. One possibility is to allow $100 \%$ of the material to pass through the $19.0 \mathrm{~mm}$ sieve and define a $12.7 \mathrm{~mm}$ sieve range for an exponent $\mathbf{n}$ of the Fuller-Talbot equation in the range of 0.4 to 0.6 and maintain a tolerance of $\pm 7 \%$.

As for the behavior of the material subjected to the tests of static and repeated loads (tensile strength, resilient modulus and fatigue), it was concluded that the results were considerably lower than those of the hot mixtures presented by Medina and Motta (2005). The results of the diametral compression tensile strength test of the cold premix indicated that this material is most suitable for use in the binder function (bonding layer immediately below the surfacing layer). In relation to the fatigue life, the differences between stresses applied were mostly less than 1,000 applications.

\section{ACKNOWLEDGEMENTS}

To CNPq (National Council for Scientific and Technological Development) for the undergraduate scholarship and the Faculty of Engineering of the Federal University of Juiz de Fora, State of Minas Gerais, for the accomplishment of tensile strength tests and dynamic tests.

\section{REFERENCES}

American Society for Testing and Materials ASTM. D 2726: Standard Test Method for Bulk Speciûc Gravity and Density of Non-Absorptive Compacted Bituminous Mixture. 2005. 4p.

Associação Brasileira de Normas Técnicas ABNT. NBR 053: Agregado graúdo - Determinação de massa específica, massa específica aparente e absorção de água. Rio de Janeiro: 2003a. 8p.

Associação Brasileira de Normas Técnicas ABNT. NBR 248: Agregados - Determinação da 
composição granulométrica. Rio de Janeiro: 2003b $6 \mathrm{p}$.

Associação Brasileira de Normas Técnicas ABNT. NBR 14376: Emulsões asfálticas Determinação do resíduo asfáltico por evaporação. Rio de Janeiro: 2007b. 2p.

Associação Brasileira de Normas Técnicas ABNT. NBR 14393: Emulsões asfálticas Determinação da peneiração. Rio de Janeiro: 1999. $3 \mathrm{p}$.

Associação Brasileira de Normas Técnicas ABNT. NBR 14491: Emulsões Asfálticas determinação da viscosidade Saybolt - Furol. Rio de Janeiro: 2007a. 8p.

Bernucci LB, Soares JB, Ceratti JAP, Motta LMG. Pavimentação asfáltica básica para engenheiros. Rio de Janeiro: Petrobras - Abeda; 2008. 501p.

Confederação Nacional do Transporte - CNT. Boletim Estatístico CNT. [acessado em: $06 \mathrm{dez}$. 2016]. Disponível em: http://www.cnt.org.br/ Boletim/boletim-estatistico-cnt

Departamento Nacional de Estradas de Rodagem DNER. ME 035: Agregados - Determinação da abrasão "Los Angeles”. Rio de Janeiro: 1998a. 6p.

Departamento Nacional de Estradas de Rodagem DNER. ME 078: Agregado graúdo - Adesividade ao ligante betuminosos. Rio de Janeiro: 1994a. 3p.

Departamento Nacional de Estradas de Rodagem DNER. ME 107: Mistura betuminosa a frio, com emulsão asfáltica - ensaio Marshall. Rio de Janeiro: 1994b. 3p.

Departamento Nacional de Infraestrutura de Transportes - DNIT. ME 135: Pavimentação Asfáltica. Mistura betuminosa - determinação do módulo de resiliência. Rio de Janeiro: 2010b. 6p.
Departamento Nacional de Infraestrutura de Transportes - DNIT. ME 136: Pavimentação asfáltica - misturas asfálticas - determinação da resistência à tração por compressão diametral. Rio de janeiro: 2010c. 6p.

Departamento Nacional de Estradas de Rodagem DNER. ME 194: Agregados - Determinação da massa específica de agregados miúdos por meio do frasco Chapman. Rio de Janeiro: 1998b. 4p.

Departamento Nacional de Infraestrutura de Transportes - DNIT. ES 153: Pavimentação Asfáltica - Pré - misturado a frio com emulsão asfáltica catiônica convencional. Rio de janeiro: 2010c. 11p.

Departamento Nacional de Infraestrutura de Transportes - DNIT. ME 156: Emulsão asfáltica Determinação da carga da partícula. Rio de janeiro: $2011.7 \mathrm{p}$.

Instituto Brasileiro de Petróleo - IBP. Informações básicas sobre materiais asfálticos. 6.ed. Rio de Janeiro: 1999. 76p.

Medina J, Motta LMG. Mecânica dos pavimentos. $2^{\mathrm{a}}$.ed. Rio de Janeiro: 2005. 570p.

Mendes LO. Utilização do método Bailey para a seleção de agregados em dosagem de misturas asfálticas [dissertação]. Juiz de Fora: Universidade Federal de Juiz de Fora; 2011.

Montanari RM. Estudo do comportamento mecânico de misturas betuminosas a frio e a quente para fins de pavimentação de vias [dissertação]. Viçosa, MG: Universidade Federal de Viçosa; 2007.

Santana H. Manual de pré-mistura a frio. Rio de Janeiro: IBP/Comissão de Asfalto; 1993. 298p.

Santos MA. Avaliação do comportamento mecânico de misturas betuminosas a frio via ensaios de laboratório [dissertação]. Viçosa, MG: Universidade Federal de Viçosa; 2002. 